as Audubon put it, 'at their natural avocations'. Again the choice of photographs is brilliant, for some are almost a perfect facsimile of attitude with the painting; others are wildly contrasted showing the unbelievable range of camera capability in skilled hands.

'The artist paints in order to see better', writes Clement, reminding us of Turner's equally apt comment: 'Every look at nature is a refinement upon art'. This book will certainly give a new boost to the unending, if fascinating, debate, but as a painter I am biased. I still recall the words of a famous and successful wildlife photographer - 'I've just come out of my darkroom and never realised what wonderful things there were in Africa'.

KEITH SHACKLETON

Handbook of the Birds of India and Pakistan, by Salim Ali and S. Dillon Ripley. Vol. 8. Warblers to Redstarts, £8; Vol. 9. Robins to Wagtails, $£ 8.50$; Vol. 10. Flowerpeckers to Buntings, $£ 11.20$. Oxford U.P.

Surface mails having reverted to the pace of sailing days, the final volume of this great work, although published in India in 1974, only reached the FPS after the October issue of Oryx had gone to press. Six years have therefore elapsed since the first two volumes were reviewed here, but there is really very little more to add to one's first impressions. This is an avifauna in the great tradition of Witherby's Handbook of British Birds, with detailed and scrupulously accurate information given under a dozen or so headings - such as field characters, status and distribution, food, voice and breeding. There is a useful cross-reference to a full description of the plumage elsewhere (often to Baker's Fauna of British India), and for the great majority of species both a distribution map and a colour illustration. A commendable feature is that, in order to reduce costs, colour plates from other books, such as Smythies's Birds of Burma, have been cannibalised, and though this leads to occasional duplication and the illustration of less common subspecies, it seems to me wholly justifiable.

Will this, one wonders, be the last regional avifauna on such a scale to succeed in getting published? Both the even more ambitious enterprises for North America and for the Western Palaearctic have run into difficulties, in the latter case largely due to burgeoning printing and other costs. I am sure the authors involved in both would be delighted to think that in six years' time their task would be successfully completed. But then this team has the unique strength of joining the greatest Asian ornithologist of modern times with an outstanding American ornithologist who has achieved the pinnacle of the Secretaryship of the Smithsonian. We expected great things of them, and they have not disappointed us.

RICHARD FITTER

\title{
Birds of Prey in Europe, by Maarten Bijleveld. Macmillan, $£ 12.50$
}

Very rarely have the fortunes or misfortunes of a group of birds been chronicled in such detail as in this dossier. In Britain we already know quite a large part of the story of the recent declines in our raptors, and now the appalling story of their systematic persecution throughout Europe is narrated in full. Both in Britain and continental Europe persecution continues on big shooting estates. Dr Bijleveld gives all the details of continuing habitat destruction, all the details of the deliberate use of poisons, all the details of deaths resulting from the use and misuse of organochlorine pesticides. He points out, too, the increasing disturbance at the nests of rare birds of prey by ornithologists taking advantage of cheap travel offered by package tours; travelling educates, but a code of behaviour seems essential. But he fails to mention the problem caused by the rash of zoos and bird gardens all wanting eagles and vultures as a public attraction. Nor does he mention as a problem the increasing demands for falconry. Perhaps this problem is not general in Europe and perhaps the 
spread of bird gardens is so modern that it was not apparent when Dr Bijleveld was researching the facts, for this book is, incidentally, his thesis for a doctorate degree.

The chapter on the decline and the present situation is the longest and by far the most dismal. Almost the only gleam of hope is in the United Kingdom where the status of the golden eagle, peregrine falcon and kite have improved following the control of organochlorine pesticides-not the control of illegal shooting on the game estates. Maarten Bijleveld thinks that there is a growing realisation of the plight of birds of prey and that some protective measures are already being taken, although some species are doomed. He concludes by stressing the importance of a coordinated plan of campaign for the protection of raptors and for public education.

This is an important book which will be the base line for studying future trends. It has a very comprehensive bibliography. But the price is high.

PETER CONDER

\section{The Mammals of Canada, by A. W. F. Banfield. University of Toronto Press, $\$ 19.95$.}

In print at last, this book has been 50 years in gestation. Nothing comparable on Canada's impressive share in the nearctic mammal fauna has appeared since Ernest Thompson Seton's Life Histories of Northern Animals in 1909, written when he was naturalist to the government of Manitoba. Great credit goes to Professor Frank Banfield for bringing to completion the task on which his three predecessors, as curator of mammals at the National Museum in Ottawa, all laboured in turn. While they amassed data and wrote checklists and papers, the implantation of their embryo was interminably delayed, until 1961 when Banfield took over. In the end therefore it is very much his book: the writing all remained to him and is greatly enriched by his personal experience.

A quarto volume of some 460 double-column pages, it is intended as a work of reference, and deals systematically with 196 species (including 33 cetaceans). The bulk of the account devoted to each species pertains to natural history, and although its style is economical it is often packed with interesting reading. Each species has a map, usually $7 \frac{1}{2} \times 6$ inches, filling more than half a page, to show its Canadian distribution, with a smaller inset of the nearctic or holarctic regions, as necessary, to indicate the world range. Such large maps allow subspecific ranges to be shown; in total they present a prodigious quantity of detail. Key references to research papers are given. There are colour plates depicting 75 species, and over 100 text-figures.

I formed two general impressions from the book. The first is the mammalian variety and wealth of this largely boreal land, confirming what I knew already from my long residence and persistent travels within it. The second is the difference that Canada is able to show, from the depressing picture of human predation, dwindling wildlife and habitat destruction so widespread in today's world. Inroads and devastations there have been, some on a ruthless scale; but they were mostly long ago, and were halted and the decline reversed before it was too late. The blackfooted ferret seems to be the only mammal lost to Canada this century. The sea otter, we are told, has been reintroduced. The slaughter of harp seals is restricted by law, and the population now whelping in the Gulf of St. Lawrence alone is estimated at 450,000. The mountain lions are now known to have survived in the forests of New Brunswick, as well as being widespread in the Rocky Mountains and British Columbia. Even the bowhead whales are said to be slowly recovering in the Canadian Arctic, though confirming data are lacking. (The right whale is still 'very rare'.) The vastness of the forests and mountains, the muskegs and barren grounds, is on her side, but Canada has done uncommonly well in practical conservation. Long may it continue, in an age when airplanes and skidoos can go anywhere, and new roads progressively lay open the recesses of the north. There must be no relaxation.

V. C. WYNNE-EDWARDS 